\title{
Opportunity costs and decision-making in peasant agriculture
}

\author{
E. S. Clayton
}

Department of Economics, Wye College, Kent, England

Received 31 May, 1968

\section{Summary}

This paper discusses the nature of opportunity costs in small-scale peasant agriculture. These are seen to be different from those of large-scale commercial agriculture and frequently difficult to discern and measure. Moreover contrary to popular notions, which have been influenced by the zero opportunity cost doctrines relating to rural labour in poor countries, the opportunity costs of labour and land within peasant agriculture are shown to be positive and often substantial. The paper illustrates these themes by examples: the nature and magnitude of factor opportunity costs which arise out of farmer decisions relating to timeliness of operations, level of yields, choice of crops, cash-crop quality and levels of mulching are analysed. The study shows that the decision-making task of the peasant farmer is frequently complicated, that because of this his decisions are sometimes misguided, that often they appear to be irrational but in fact are not so once the scale of opportunity costs and farmer objectives are taken into account, that the frequent divergence between technical and economic efficiency in peasant agriculture is due to the crucial role played by factor opportunity costs at the farm level.

\section{Introduction}

On seeing the title of this paper, the reader is likely to ask "Why specially refer to opportunity costs in this particular context instead of the more commonly used term costs of production?' After all in theory there should be no distinction between these two terms. For, in a competitive system, with free factor mobility, factor prices will reflect their alternative productivities, product prices will be proportional to the value of factor opportunities, these will total to cash costs of production and therefore be synonymous with total opportunity costs.

However, in small-scale agriculture which typifies the rural sector of most developing countries, this theoretical synomymity does not hold because the assumptions of a competitive system do not wholly apply to it, neither do the capitalist characteristics of the agricultural sector of the developed countries. This is so because, in the first place, the markets in the agricultural sector of poor countries, for both factors or products, tend to be narrow and inadequate. Large distances, poor communications, uncertain transport systems, the absence of market information which is a concomitant of a closed society; all of these are commonly known to reduce the efficiency of

* I am grateful to my colleague Mr. Ian Carruthers, who read the first draft of this paper, for his helpful comments. 
the market system. And to the extent that this occurs, there will clearly be a divergence between cash costs of production and factor opportunity costs. Factor opportunity costs measure the use of real resources in a society and if these are not accurately quantified by cash production costs then miscalculation may well occur and with it a serious misuse of resources.

In the second place, the production of agricultural products in poor countries is very largely associated with non-cash factor costs; in which case, a reckoning of the costs of using real resources can only be done in opportunity terms, both from the farmer and sectoral points-of-view. Most of the land worked by peasant farmers is held under customary, communal tenure arrangements. Ordinarily there is no market for this land, it possesses therefore neither a capital nor a rental value, whatever its productivity. In working it, therefore, the cultivator incurs no capital nor rental cash payments. The peasant holding is also usually worked by family labour and the farmer thereby avoids cash payments for farm labour. Thus, the employment of the two basic productive resources of peasant agriculture do not involve any cash outlays. The absence of cash costs obviously does not imply that the use of these resources is 'costless', but rather that their use involves the farmer in opportunity costs. These are not clearly apparent like cash production costs - even to the cultivator they are sometimes difficult to discern and often difficult to measure. This makes the decision-making calculus of the peasant farmer very complex, a fact which is often not clear to those more familiar with the problems of large-scale, capitalist agriculture.

Many other resources enter the peasant production process which incur no cash outlay and in some cases no opportunity costs to the farmer. For example, cattle fodders, materials for farm buildings and tools are frequently gathered from the public domain' which, in some cases, will be free goods to the agricultural sector.

Two oft-repeated generalisations concerning rural labour supplies lend support to this contention of costless resources in peasant agriculture. It is commonly held, for example, that the opportunity cost or supply price of rural labour is zero, firstly to the agricultural sector and secondly to the non-agricultural sector. In the former case, the absence of employment opportunities outside agriculture, for the bulk of the population, implies its costless availability to agriculture (disregarding leisure preference), But even where this is so, in overpopulated countries, it is a statement of limited value. Its corollary is that labour can be economically employed in the agricultural sector until its marginal productivity is zero, thereby maximising total agricultural production. Of course, common sense and observation tells us that rural labour can contribute to total welfare, other than through the non-agricultural sector. For example, the use of 'leisure' time for do-it-yourself household activities, for nonfarm domestic tasks or even for enjoyment. These foregone opportunities are invariably reflected in a positive rural wage which determines the level of rural employment and results in a level of agricultural production below the maximum. This so-called 'lost production' is, however, only relevant to the extreme, zero opportunity cost case which, as can be seen, is not generally applicable. Of course, where a statutory minimum rural wage operates which pays no heed to opportunity costs, it is an impediment to economic production.

The zero supply price of rural labour to the non-agricultural sector is meant to describe densely populated communities. Here the rural population is so excessive that, after obtaining maximum agricultural production, much of it is unemployed or underemployed. There is, therefore, available a wholly elastic supply of rural labour to 
develop the non-agricultural sector, the use of which will in no way reduce the level of agricultural production. This also turns out to be a dubious generalisation for the crucial parameter in this context has been found to be that of seasonal labour demands. Empirical studies have shown that the characteristic peak demands for farm labour tend to fully employ the rural population for short critical periods in the farming calendar. Given this seasonal labour constraint, it seems that only a limited amount of the rural population could be transferred into the urban sector before adversely affecting the level of agricultural production (Kao, Anschel and Eicher, 1964).

As far as the problem of resource disposition, at the farm level, is concerned the crucial point is the opportunity cost of rural labour, not to the agricultural sector nor to the non-agricultural sector but within the agricultural sector. And here, the dubious assertions of zero labour opportunity costs to agriculture and non-agriculture have tended to obscure the existence of positive labour opportunity costs within peasant agriculture. It is the object of this paper to show that these can be large and of fundamental importance. This object is of course not new, as is shown by Table 1 from Bauer's classic study of the Malayan rubber industry, but its' implication is too often neglected.

Table 1 Net returns of rubber and rice in some years

\begin{tabular}{cccc}
\hline Year & $\begin{array}{c}\text { Net returns/ac. of } \\
\text { rubber (in terms of } \\
\text { gantangs of rice) }\end{array}$ & $\begin{array}{c}\text { Net returns/ac. } \\
\text { of rice } \\
\text { (gantangs) }\end{array}$ & $\begin{array}{c}\text { Balance in } \\
\text { favour } \\
\text { of rubber }\end{array}$ \\
1929 & 273 & & \\
1930 & 150 & 53 & 220 \\
1931 & 114 & 43 & 107 \\
1932 & 86 & 71 & 43 \\
1933 & 156 & 80 & 60 \\
\hline
\end{tabular}

Source: P. T. Bauer. The Rubber Industry. London 1958.

Table 1 shows the production possibilities facing smallholders, in the rice/rubber ecology of Malaya, over a period of years when product prices were fluctuating widely. It will be clearly seen why, even in the depths of the 1932 depression, Malayan smallholders acutely aware of the opportunity costs and relative profitability of these two crops, continued to grow rubber and hence frustrate a government policy of extending domestic rice production. Throughout the period the farmer could obtain more rice, for his family needs, from the proceeds of rubber than by growing it direct. Indeed, the shrewd Malayan peasant would be aware that his opportunity costs of growing rice were not only positive but in most years enormous: and, though unaware of comparative cost doctrine, he would pursue a policy of farm specialisation despite significant price instability.

\section{Economics of labour use}

The peasant farmer then employs two basic resources which generally incur no cash outlays but the use of which are not 'costless'. From the farmers' point of view, 
farm labour can be put to many alternative uses (growing a wide range of crops) and if its supply is limited its allocation to one task (crop) will mean that other alternatives (crops) are foregone and consequently the existence of positive opportunity costs within the agricultural sector. In the same way, crop enterprises will compete for the limited land area of the holding and the selection of a particular cropping pattern will imply that some cropping alternatives have been foregone and these will reflect the opportunity costs of employed land and labour resources. This is an important aspect of peasant economics which, though obvious to the economist, is not well-conceived by agriculturists nor, in many cases, by the cultivator himself. Yet a knowledge, however approximate, of the opportunity costs prevailing within various farming systems is essential if correct decisions are to be made on the farm as well as within the agricultural economy (Belshaw and Hall, 1965).

\section{Peak labour demands and farm practices}

Two basic decisions facing the peasant farmer concern the allocation of his land and labour resources between feasible crops or enterprises and the intensity of labour application to the various enterprises. In traditional, subsistence agriculture, these decisions are by no means straightforward. In a hand-labour farm economy, for example, where labour is the limiting factor, the problem is one of balancing the food crop acreage with intensive labour use. The pattern of farm operations which the peasant farmer undertakes differs from that of the commercial, mechanised farmer. The normal procedure for the large arable farmer is to prepare all his land prior to planting of the crop(s). But the tropical smallholder, dependent on hand labour, will normally prepare a small plot of land which he then plants, he then prepares another area and plants it and so on. This is his logical reaction to an uncertain rainfall and predominantly subsistence objective. Not long after starting this prepare/plant strategy, the cultivator finds that the first planted area requires weeding and he is then faced with a critical economic decision of whether to weed or continue preparing and planting more land (Kennedy, 1963). Early and continuous weeding will result in a higher yield per acre but it will also limit the total acreage planted and delay the average sowing date of the planted area. Planting up as large an area as possible will, on the other hand, result in an earlier average sowing date but a low average yield due to inadequate weeding.

Here is, indeed, a neat exercise in the balancing of opportunity costs which is a consequence of constricting peak demands for farm labour. In the subsistence economy, the farmers' objective is to maximise food output which may not derive simply from high average yields; this is a matter of technical coefficients at the intensive and extensive margins of cultivation. If average returns to labour at the latter are greater than at the former margin, then food production will be maximised from a relatively large cropped acreage producing relatively low crop yields. Subsistence cultivators, it appears, commonly consider this to be the situation, to the despair of agricultural extension officers who complain of deplorable levels of husbandry (badly weeded crops) and consequent low yields due to too great an area being cropped. This is the usual conflict between technical and economic efficiency where the recommended policy of good husbandry (clean weeding) and high yields pays no heed to the opportunity costs such a policy involves. Farmers' decisions appear to be irrational because labour opportunity costs in the plant/weed period are ignored. 
Timeliness, maximum yields and choice of crops

When we move out of the subsistence phase into one in which the earning of a cash income becomes an additional, important objective of the peasant cultivator, usually involving cash-crop production, then the disposition of limited though multipurpose resources can involve substantial opportunity costs. For example, in the coffee/maize ecology of East Africa, the decision to seek high maize yields, by timely and adequate weeding, will conflict with operations affecting the yield and quality of the coffee crop. In the long rain season, it will affect pruning operations which influence coffee yields and in the short rain season, it will affect coffee harvesting and thereby reduce quality. Where, for example, the gross output of an acre of coffee is worth $£ 150$ and of maize $£ 10$, modest gains in the value of maize production due to timely weeding, will involve a significant reduction in the value of coffee production due to inadequate pruning or late harvesting. Technical decisions, that is, to pursue better cultural standards to achieve higher yields in maize production will incur substantial labour opportunity costs.

Where annual, rather than perennial, cash crops enter the farming system another cultural practice assumes some importance - that of timeliness in planting. For example, in a cotton/maize ecology, if the motive to safeguard family food supplies is strong the tendency will be to plant a high acreage to maize and to weed it well to secure high yields in order to achieve the objective. This policy would inevitably effect the cotton planting date(s) and therefore cotton yields which, as shown in Table 2, are notoriously sensitive to planting date. From this table it will be seen

Table 2 Effects of delayed sowing on yield of cotton. Some typical example. taken from recent E.C.G.C. Progress Reports. (Figures given represent percentage of the yield from the optimum sowing date)

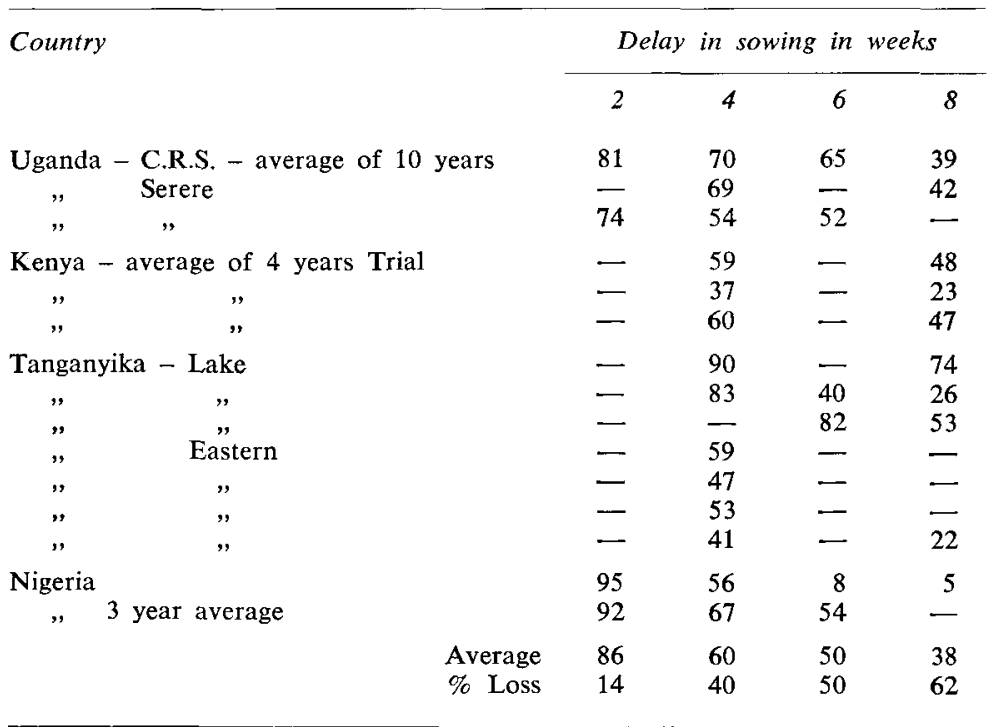

Source: D. F. Ruston. Effects of delay in sowing cotton. A paper in: Report of a Technical Conference of Directors of Agriculture, etc. held at Wye College, 1961. Misc. Report No. 2 Dept. of Tech. Cooperation. London 1962. 
that, under rain-grown conditions, a delay of two weeks beyond the optimum sowing date leads to an average reduction in yield of $14 \%$; a delay of four weeks leads to a $40 \%$ loss of the potential crop and a delay of six weeks to a $50 \%$ loss. As Ruston says 'When this is considered in the light of production from any one country, the results are even more impressive'. For example, for a country whose production with optimum sowing would be 500,000 bales, a delay of four weeks (which is by no means unusual) would mean a loss of 200,000 bales. At an average price of $£ 50$ a bale, this would mean a loss in revenue to the country of $£ 10$ million (Ruston, 1962, p. 80).

In this situation, economic and technical optima may converge. Departments of Agriculture in Africa have for long resounded with the cry of 'plant cotton early'; the pursuit of high-yield (though low-valued) maize or millet involves a reduced cotton yield, i.e. the foregoing of relatively high-value production. The safeguarding of food supplies, that is, can incur substantial opportunity costs (measured in terms of foregone cotton). The basic subsistence objective of traditional African agriculture is so deep-seated, that year after year, poverty-stricken small farmers willingly incur these heavy opportunity costs to offset, they suppose, the risks attending food production. The result invariably is a limited area of late-planted and low-yielding cotton (Kennedy, 1963 ; Russell, 1965).

Of course, the right decision will depend on relative cost and price ratios. Where gross margins of cotton are significantly higher than those for food crops and where there is an established internal market for these latter, then the net returns from early cotton planting will substantially exceed the opportunity costs (foregone food crops) so incurred. But where farmers are only able to grow short-stapled, low quality cotton and where there is no established market for foodstuffs, then the (much lower) factor opportunity costs of early food crop planting (the yields of which are equally sensitive to date of planting, see Table 3) may be justifiably incurred to reduce the risk factor of an uncertain food supply and the limited area of late-planted and lowyielding cotton' may be the optimum 'choice of technique'.

For the agronomists, however, it is taken as axiomatic that early-planted cotton is the right decision. The following quotations illustrate this point, (thus) it has now been repeatedly confirmed that cotton yields for this area are at an optimum when sown about mid-June. Therefore the preceeding crop itself must be an early maturing,

Table 3 Maize yields (lb/ac.) for three 'time of planting' experiments at llonga, Tanzania

\begin{tabular}{|c|c|c|c|c|c|}
\hline \multicolumn{6}{|c|}{ Date of planting and yield $(\mathrm{lb} / \mathrm{ac}$.$) in:$} \\
\hline \multicolumn{2}{|c|}{1957} & \multicolumn{2}{|c|}{1958} & \multicolumn{2}{|c|}{1961} \\
\hline $11 / 1$ & 3176 & $3 / 1$ & 2543 & $6 / 2$ & 3217 \\
\hline $14 / 2$ & 716 & $11 / 2$ & 1236 & $14 / 2$ & 3176 \\
\hline \multirow[t]{3}{*}{$1 / 3$} & 290 & $27 / 2$ & 1857 & $22 / 2$ & 3011 \\
\hline & & $11 / 3$ & 1183 & $2 / 3$ & 2900 \\
\hline & & & & $10 / 3$ & 2600 \\
\hline
\end{tabular}

Source: Akehurst and Sreedharan. Time of planting - A brief review of experimental work in Tanganyika. 1956-62. East African Agricultural and Forestry Journal. January 1965 . 
though possibly lower yielding variety of maize'. And again 'crop combinations must be determined by the climate pattern rather than economic desirability' (Manning, 1962). These are indeed interesting reactions to the criticism of a cotton agronomist that work, at a well-known cotton research station in East Africa, had entirely ignored the position of cotton in local farming systems (Hutchinson, 1958). In both these cases, the opportunity costs of growing cotton were assumed to be negligible.

\section{Economics of cash-crop quality}

Farmers' decisions on produce quality, particularly those concerning cash or export crops, are not always without ambiguity. Basically his decisions depend upon balancing costs and returns at the margin. If he aims at improving the quality of his produce, then the extra revenue for this better quality must exceed the extra costs of achieving it. If he decides to lower produce quality, then the saving in costs must exceed the loss in revenue due to poorer quality. So, on the face of it, this seems to be the sort of simple equation which, in other situations, farmers can and do resolve easily.

But problems of measurement and ambiguity of definition present difficulties at both the farmer and economy level, which often results in a farmer pursuing a misguided policy - usually that of producing a lower rather than a higher grade produce. For example, in reckoning changes in marginal costs and returns arising from a variation on quality, the farmer is likely to impute a value to any family labour involved in the operation. Often, and particularly in a period of social change, he will impute to it an unduly high value, in the short-run. This could arise because he relates the value of family labour to the wages of hired labour; but these are often an imperfect measure of the true supply price of labour. He will also have to estimate the value of his improved produce; but the actual quality or grade he will achieve is, of course, uncertain and this is most likely to lead to undervaluation of the gains from better quality. Both of these examples would result in a position short of the optimum, which means that the quality aimed at will be below that which would maximise the farmers' income.

Decisions affecting improved quality often require improved cultural operations; in some cases, such as spraying, they involve direct cash costs, in other cases, such as early planting, they incur factor opportunity costs. Sometimes, these improved practices require increased care and concentration and perhaps loss of family leisure, for example, plucking tea. In these cases, the reckoning of costs will be in terms, not of tangible foregone opportunities, but of intangible personal experience and here the assessment of an optimum grade policy will involve the direct intrusion of a value judgement, on the part of the farmer, which will tend to produce an ambiguous result.

So much for the static consideration of the problem, but there is also a dynamic aspect which the individual farmer will find difficult to build into his personal equation. The gains from improved quality not only affects the farmer's income directly but they will probably have wider multiplier effects on the economy of the country. These will bring a second round of benefits to the farmer, either direct or indirect, which he will ordinarily not take into account. Then there is the question of stability of income as well as the level of income. With many export crops, it can be observed that prices of the top grades are more stable, whether the trend is 
Table 4 Percentage annual fluctuations in grade prices to Kenya coffee farmers

\begin{tabular}{|c|c|c|c|c|c|c|}
\hline \multirow[t]{2}{*}{ Class } & \multicolumn{6}{|c|}{ \% change } \\
\hline & $\begin{array}{c}1956- \\
1957\end{array}$ & $\begin{array}{c}1957- \\
1958\end{array}$ & $\begin{array}{c}1958- \\
1959\end{array}$ & $\begin{array}{c}1959- \\
1960\end{array}$ & $\begin{array}{c}1960- \\
1961\end{array}$ & $\begin{array}{c}\text { Mean } \\
1956-1960 \\
\%\end{array}$ \\
\hline 1 & +14 & -7 & -5 & 0 & -4 & 6 \\
\hline 2 & +13 & -6 & -5 & +1 & -12 & $71 / 2$ \\
\hline 3 & +14 & -10 & -7 & +1 & -20 & 10 \\
\hline 4 & +17 & -15 & -7 & +2 & -23 & 13 \\
\hline 5 & +17 & -21 & -8 & -1 & --17 & 13 \\
\hline 6 & +17 & -20 & -14 & -2 & -13 & 13 \\
\hline 7 & $\begin{array}{r}17 \\
+17\end{array}$ & -21 & -17 & -5 & -6 & 13 \\
\hline 8 & +17 & -21 & -18 & -4 & -4 & 13 \\
\hline 9 & +17 & -21 & -17 & -3 & -6 & 13 \\
\hline 10 & +17 & -21 & -18 & -2 & -4 & 13 \\
\hline 11 & +11 & -7 & -23 & +2 & -5 & 10 \\
\hline 12 & $\begin{array}{l}1 \\
+\quad 8\end{array}$ & -3 & -16 & -3 & -20 & 10 \\
\hline 13 & +10 & +24 & -31 & -9 & -33 & 21 \\
\hline 14 & +9 & +42 & -56 & -30 & -54 & 38 \\
\hline
\end{tabular}

rising or falling, than prices of the lower grades. Table 4 illustrates this point. It follows, therefore, that an active policy to improve quality may achieve not only a higher farm income, because of better prices, but also a more stable income. The possibility of this second advantage is not likely to be known to the farmer, and if it is, it will be difficult to give it a quantitative value.

These few examples will serve to show how difficult it is for the farmer to select a rational policy with regard to quality and also how the decisions he takes may often be contrary to his own interests.

\section{Economics of mulching}

It is common practice to apply a mulch to certain perennial crops like tea and coffee ${ }^{1}$. One purpose of a mulch is for soil conservation, that is to minimise the risks of soil erosion. But its major purpose is for moisture conservation. Trials and experience have proven the value of this practice in raising yields and the field tests (Table 5) indicate the magnitude of benefits that follow from the mulching of coffee in Kenya. The contrast between the yields with no mulch in these dry and wet years shows how devasting the effects of no mulch can be - in 1950 there was scarcely a crop worth picking. The mulching of all rows achieves the remarkable effect of virtually doubling the yields over the control.

If a farmer, with one acre of coffee on his holding, could achieve these results, would he be economically justified in mulching his coffee crop? On the face of it, the answer appears obvious. If we take the more common 1951 experience and assume the farmer receives $£ 300 /$ ton for his coffee then, without mulch, his one acre of coffee produces a gross output of $£ 102$ and with mulch his gross output

1 This theme was first discussed by the author in a contribution to P. von Blanckenburg and $\mathbf{H}$. $\mathbf{D}$. Cremer: Die Landwirtschaft in der wirtschaftlichen Entwicklung. Stuttgart, 1967. 
Table 5 Coffee yields, showing response to grass mulches (cwt. clean coffee per acre)

\begin{tabular}{ccccc}
\cline { 4 - 5 } Year & $\begin{array}{c}\text { Annual } \\
\text { rainfall }\end{array}$ & $\begin{array}{c}\text { Control } \\
\text { no mulch }\end{array}$ & $\begin{array}{c}\text { Mulched } \\
\text { all rows }\end{array}$ & $\begin{array}{c}\text { Mulched } \\
\text { alternate } \\
\text { rows }\end{array}$ \\
1950 & 24 & 0.76 & 1.52 & 1.09 \\
1951 & 54 & 6.81 & 12.08 & 10.58 \\
\hline
\end{tabular}

Source: Pereira and Jones. Field responses by Kenya coffee to fertilisers, manures and mulches. Empire Journal of Experimental Agriculture, 22 (1965) No. 85.

is $£ 181$. Hence the gross value of additional output is $£ 80-$ a significant addition to a peasant farmers' income. But what additional costs are incurred to achieve this?

The usual material used for mulching in Kenya is Napier grass (Pennisetum purpureum) which is a costly crop to produce. It has heavy labour demands for planting, weeding, cutting and carrying - at least 50 mandays an acre — and it is a gross feeder requiring the application of manure or fertiliser. Furthermore, it is officially recommended that the production from one acre of Napier grass is required to mulch, at an adequate moisture-conserving level, one acre of coffee. But if all the imputed and cash costs expended on an acre of Napier were added up, they would not equal $£ 80$ which implies that mulching is economically as well as technically desirable from the farmer's point of view.

What this calculation does not take into account, however, is the fact that on his limited acreage the land given over to Napier grass could also grow coffee and, therefore, that a normal rent imputed to this land would fall far short of the opportunity costs of putting it into Napier grass production. Looked at from this point of view, the true (opportunity) cost of mulching one acre of coffee is equal to the product from one acre of (unmulched) coffee which could otherwise be grown if the original acre of coffee remained unmulched ${ }^{2}$. This is the real economic choice facing the farmer (or positions between indicating different levels of mulching). The magnitudes he has to balance, therefore, are the gains from mulching (all rows) at $£ 80$ and the costs of mulching at $£ 102$. It appears to be a practice which, though technically desirable, costs more than the benefits it produces. In this particular ecology, it is a practice which incurs very high opportunity costs and thus a lower level of treatment may be more economic. Indeed, if the consequences of mulching alternate rather than all rows are considered, this will be seen to be so. The gain from mulching an acre, in this case, is $£ 57$ ( $£ 159-£ 102$ ) and the cost (half an acre of mulch to one acre of coffee) is $£ 51$, giving a net benefit of $£ 6$. Mulching alternate rows is, therefore economically as well as technically justifiable.

From an exclusively mulch point of view, a half mulch is the optimum policy for the farmer to select followed closely by a zero mulch policy. With a full mulch, the net return from two acres (one acre coffee one acre mulch) would be $£ 181$; with a half mulch, the net return from two acres $(11 / 3$ acres coffee $2 / 3$ acre mulch) would

2 Assuming that the family labour required for an acre of unmulched coffee, in excess of that required for an acre of napier grass, comes from leisure. 
be $£ 212$; and with no mulch, the net return from two acres (two acres coffee zero acre mulch) would be $£ 204^{3}$. In an economic sense, therefore, an optimum decision requires a desirable, though not essential, technical farm practice to be dispensed with. Indeed, it is significant that since the extension service of Kenya adopted a more permissive policy, after Independence, small coffee farmers have responded to their own assessment of Napier mulch opportunity costs. It is now rare to see heavy mulches anywhere in the coffee areas and, of course, average yields have fallen. Napier grass has ceased to be grown as a coffee mulch and is now grown as fodder for lucrative milk production.

Of course, this example relates to one ecology; a different one, giving more efficient Napier grass production, could well result in light rates of mulching being an optimum policy. Above all where suitable by-products are available, such as maize stover, banana trash or grass from anti-erosion terracing, the use of these low-cost mulching materials would produce an altogether more favourable calculation. In Kenya, the light coffee mulching that is now practiced comprises available crop byproducts. But the point of the previous examples is to illustrate the kind of decision and the real level of opportunity costs which can face peasant farmers.

\section{References}

Akehurst and Sreedharan, 1965. Time of planting - a brief review of experimental work in Tanganyika. East African Agricultural and Forestry Journal, (Jan.).

Belshaw and Hall, 1965. The analysis and use of experimental data. Proceedings 2nd Conference East African Economists, Nairobi.

Hutchinson, J., 1958. The objectives of research in tropical agriculture. Empire Cotton Growing Review, (Oct.).

Kao, Anchell and Eicher, 1964. Disguised unemployment in agriculture. A survey. Paper in Eicher and Witt: Agriculture in Economic Development.

Kennedy, T. J., 1963. A study of economic motivation involved in peasant cultivation of cotton. East African Economics Review, 10 (No. 2).

Manning, H. L., 1962. The importance of the Namolonge farming system to farm planning in Buganda. Misc. Report No. 2. Dept. of Tech. Cooperation, London.

Russell, W., 1965. Some agricultural problems of the semi-arid areas. Symposium on soil resources of tropical Africa. African Studies Ass. of the U.K.

Ruston, D. F., 1962. Effects of delay in sowing cotton. Misc. Report. No. 2. Dept. of Tech. Cooperation, London.

$3 \quad$ See footnote 2 . 